\title{
Printed or Digital Qur'an? The Voices of Young Muslims in the Digital Era
}

\author{
$1^{\text {st }}$ Desi Nahartini ${ }^{1}, 2^{\text {nd }}$ Mumin Roup ${ }^{1}, 3^{\text {rd }}$ Rena Latifa $^{1}, 4^{\text {th }}$ Imam Subchi $^{1}, 5^{\text {th }}$ Husni Teja \\ Sukmana \\ $\left\{\right.$ desi@uinjkt.ac.id ${ }^{1}$ \}
}

UIN Syarif Hidayatullah Jakarta, Indonesia ${ }^{1}$

\begin{abstract}
This study is intended to voice the use of digital Qur'an by Islamic university students. In the midst of the digital age and the increase of various types of digital applications that increasingly facilitate human life, it turns out that the presence of digital Qur'an as a substitute for printed Al Quran still need to be revisited from several aspects. The respondents of this study are 137 students studying at Islamic universities. The results of this research indicate that there is still the need to use the printed Qur'an. Students feel that they cannot leave the printed version of Qur'an or have not yet fully switched to digital Qur'an. This is due to several factors, namely: (1) there is still some questions about reading the Qur'an, whether to perform ablution or not before reading the digital Qur'an, (2) the digital Qur'an has been reported to be less comfortable than the printed Qur'an because several students stated that their eyes is irritated and tired when reading Digital Quran in a long duration.
\end{abstract}

Keywords: digital Qur'an; young muslim; digital era

\section{Introduction}

The Internet massive advancement has brought about many changes in human life, ranging from stimulating different modes of communication, transportation, knowledge hunting and worshiping. Naisbit [1] stated that this condition is referred to the Technological Drunk zone, which characterized by a complex relationship between humans and technology. The Internet World Statistics (2012) noted the increase of the internet users to five times during 2000 - 2012. This signs that more than 2 billion $(30 \%)$ of the world's population uses the internet and approximately $25 \%$ of those are Muslims [2]. Various usage of the internet are employed by the Muslims. Razaly[3], Elhadj[4], and, Yahya [5] reported that the internet is used for conducting online education, teaching Al Qur'an, doing Online business, banking, spreading information, and communicating. Some studies even reported that the internet was also used by the Islam radical group to spread propaganda and violent ideologies [6, 7].

Massive usage of the internet was more or less also stimulated by the appearance of smartphones and android-based gadgets in 2007. Android itself is a Linux-based operating system designed specifically for mobile phones. Abundance sources of information has flooded human by the existence of the internet deployed through the application on their mobile phones 
Smart phones and gadgets then become inseparable to human daily activities. It then turns to become a soul mate for a human. People will take their phone to wherever they go, both to Formal and nonformal occasions. The development of the smartphone application then has grown so rapidly. Several applications were then developed to support religious activities, including Islamic ritual activities. Currently there have been many applications for Androidbased Islamic content such as Al-Quran[8], Hadith[9], zakat [10], Tajweed [11], memorization of the Koran [12], prayer[13], Fiqh [14], etc. Inspite of the diversity of the application available in the smartphone, some study noted that more concern is given to the Al Qur'an digital application. There are even some Al Qur'an digital application to support people with disabilities[15] and early childhood[16]. A small research conducted on September 17, 2018, using "the Qur'an" as the keywords in play store revealed that there are 253 application of the digital Qur'an, both free and paid.

Each Al Qur'an application has different features. For example, the Pro Qur'an application has listed the best Qur'anic readers in the world, such as Abdul Rahman Al-Sudais, Sheikh Mishary Rashid Alafas, and Sheikh Saad al Ghamedi. This application developed by Quanticapps Ltd, London. In addition, its simple appearance also makes readers feel that they read the printed version directly. Furthermore, it can be read offline. Another example is the Indonesian Qur'an version which contains a complete Qur'an and provides Indonesian translations. It even provides word by word translation. The Indonesian version is not only has an attractive appearance but it is also easy to use. Additionally, this Qur'an version has a "verse sharing" feature, a prayer time reminder and a Qibla compass. The "search" feature is also provided to provide reader with several information related to the Qur'an. Another research that build a digital print to learn islamic is done by Atqia et.al.[18]

More than fifty percent of thousands of android users around the world are teenagers.[17] This also the case in Indonesia. Downloading easily and freely from the play store has attracted the teenagers to express themselves by downloading unique application for social media, game, camera and photography.

The digital era is just like two sided of coins. In one hand, it provides a benefit for human and on the other hand, it provides a negative impact as well. Although many people has rejected the digital technology acceleration, they actually can feel the benefits of the advancement of technology.

With the technological enhancement, there is not again any reason of difficulty of accessing to Qur'an. One can easily get any information about the Qur'an, its verses, its translation version and so on. The Qur'an application can be accessed online or offline. The software version of Qur'an is more practical to be carried and can be read anywhere. Considering this condition, this article is aimed to investigate the use of digital Qur'an by the Islamic University students. This paper will uncover whether the easy access to read the Qur'an supported by the technological advancement affected the intensity of reading the Qur'an among the young generation in Indonesia.

\section{Literature Review}

Literally, Qur'an means “reading” or "a collection”. However, the definition of Al Qur'an has grown overtime. Al Qur'an nowadays is not only reading materials but also research materials. This definition has differentiated between Qiraah (reading) with tilawah (reciting). Reading Qur'an using good mind is called the Qira'atul Qur'an, while reading the Qur'an only 
verbally is called Tilawatul Qur'an. Another literal meaning of the Qur'an is a collection of materials that must be read and studied. Muslims believe that Qur'an was mu'jizat (miracle) revealed by God to prophet Muhammad through the angel of Gabriele with the pronounce and meaning from Allah SWT. The Qur'an is divided into surah (chapters) which are then divided into verses. The Qur'an starts with surah Al-Fatihah and ends with surah An-Nas. Indeed, the Qur'an is a noble reading. The Qur'an is a book that proves Muhammad SAW as the prophet of Allah SWT. KH. M. Quraish Shihab strengthen this case by stated that the Qur'an is commonly defined as "the words of God delivered by the angel of Djibril of the lord to Prophet Muhammad SAW and accepted in humility (tawatir)".

When we look closely to the word Qur'an, it appears about seventy times in the Qur'an book itself, giving various different meaning. It is known as the verbal noun form (masdar) of the Arabic verb qara' $a$ which meand "he read" or "he recited". An important meaning of the word Qur'an is the "act of reciting", as reflected in an early Qur'anic passage, "it is for us to collect it and to recite it (qur'anahu)".

Along with the invention and development of new science and technology, the digital version of the Qur'an was born. In Indonesia, the reuters has been reported that the first emergence of the digital Qur'an is around 2007. The digital version of the Qur'an has been increasingly populare since then in Indonesia. This application then experienced much advancement into application which can be downloaded in the smartphones.

The application advancement was really supported by both the private and the government sector in Indonesia. Detik.com reported that on the 30th of August 2016, the Ministry of Religious Affair has launched the official digital Qur'an application developed by the Indonesian Ministry of Religious Affair. The minister, Dr. Lukman Hakim Saifuddin in the event stated that "he hopes that this application could progressively improve both the contents and the facilities".

In this research, the term digital Qur'an refers to the Qur'anic text which are processed and spread as an electronic text and or more specifically refers to an electronic device used to display the text of the Qur'an and playing digital recording of Qur'an recitations. One example of the Qur'anic software on CD-Rom has been developed since the early 1990s. However, with the presence of more powerful smartphones, the focus has changed on the production of Qur'anic software for such devices rather than dedicated digital Qur'an devices.

Several features are noted to be available in the digital Qur'an application, such as audio playback of recorded recitations of the Qur'an with synchronized on screen Arabic text, basic navigation of the Qur'an with the ability for the user to select a specific surah (chapter) and verse, and other languages translation including bahasa Indonesia translation which sometimes synchronized with the original Arabic recitations. With several benefits found in digital Qur'an, this should call for the increasing of better understanding of the Qur'an and the increasing of better Muslims that applied Islamic norms and traditions especially among the young generation

\section{Research Methods}

The participants for this study are Islamic University students $(\mathrm{N}=137)$. Most of the respondents studied at religious department $(55.5 \%)$, and the rest studied at non- religious department (44.5\%). Most of the respondents are female $(60.6 \%)$ and others are male $(39.4 \%)$. 
They have different educational backgrounds, coming from general high school has the highest rank which is $38.7 \%$, followed by pesantren (Islamic boarding school) which is $32.8 \%$ and the last is Madrasah (Islamic based school) which is $28.5 \%$.

The Instrument are a questioner consist of 15 questions related to the Al Qur'an digital utilization are deployed to gain the data. The questions were mainly made to find out the descriptive statistical data related to (1). Whether the students have the digital version of Qur'an, (2). Preferences or fondness of the digital version of Qur'an, (3) the frequency of reading the digital version of Qur'an, (4) whether the procedure for using digital Quran is similar to using non-digital Quran, and (5) the benefits of using digital Quran. Statistic descriptive is occupied to analyze the data, using SPSS software.

\section{Results}

Presented below in table 1 is the finding of this study which is the owner of the printed and the digital version of the Qur'an.

Table 1.A

\begin{tabular}{|c|c|c|}
\hline $\begin{array}{c}\text { Having both } \\
\text { Digital Qur'an } \\
\text { and Printed } \\
\text { Qur'an }\end{array}$ & $\begin{array}{c}\text { Having only } \\
\text { digital Qur'an }\end{array}$ & $\begin{array}{c}\text { Having printed } \\
\text { Quran only }\end{array}$ \\
\hline $\begin{array}{c}110 \\
\text { respondents }\end{array}$ & 2 respondents & 23 respondents \\
\hline
\end{tabular}

The data revealed that the majority of students at Islamic University, 110 respondents out of 137 respondents, have both digital and printed Qur'an, This data also proved that only 2 people have digital Qur'an only. The data indicated that there is still a need to use printed version of Qur'an. Students feel that they cannot leave the printed Qur'an and have not yet fully switched to digital Qur'an.

Table 1.B. Features of Digital Qur'an Available on The Students' Downloaded Version

\begin{tabular}{|c|c|}
\hline $\begin{array}{c}\text { Features available in the downloaded } \\
\text { digital Qur'an }\end{array}$ & Total respondent \\
\hline $\begin{array}{c}\text { Verses, bilingual (Arabic and } \\
\text { Indonesian translation), audio, tajwid }\end{array}$ & 46 \\
\hline $\begin{array}{c}\text { Verses, bilingual (Arabic and } \\
\text { Indonesian translation), audio }\end{array}$ & 61 \\
\hline $\begin{array}{c}\text { Verses and bilingual (Arabic and } \\
\text { Indonesian translation) }\end{array}$ & 24 \\
\hline Verses only & 6 \\
\hline
\end{tabular}

Table 1.b above explains that the majority of respondents (131 respondents) have not only the Qur'an verses features, but also the Indonesian translation feature, audio and even the tajwid recitation. This fact remind us that various features available in the digital Qur'an is important for the young Muslim. Furthermore, table 2 presents the young Muslim fondness to digital Qur'an usage.

Table 2. 


\begin{tabular}{|c|c|c|}
\hline $\begin{array}{c}\text { Very fond to use } \\
\text { digital Qur'an }\end{array}$ & $\begin{array}{c}\text { Fond to use } \\
\text { digital Qur'an }\end{array}$ & $\begin{array}{c}\text { Dislike to use } \\
\text { digital Qur'an }\end{array}$ \\
\hline 40 respondents & 80 respondents & 17 respondents \\
\hline
\end{tabular}

From Table 2, we can see that some Islamic university students are less happy to use digital Qur'an, which are 17 respondents. It is interesting though to explore this phenomena on further research. The students are known as the millennial generation who prioritize practicality and modernization, however it seems that the students are still affected by the Islamic culture and tradition which placed Al Qur'an as a sacred book and cannot be replaced with the digital form. The young Muslim reasons for using digital Qur'an are presented in the following table:

Table 3. The Reason of Using Al-Quran Digital

\begin{tabular}{|l|l|}
\hline Reasons: & Total Respondents \\
\hline $\begin{array}{l}\text { Can be read anytime and } \\
\text { anywhere }\end{array}$ & 74 \\
\hline Practicality, easy to be carried & 38 \\
\hline Easy to search specific verses & 24 \\
\hline As a collection & 1 \\
\hline
\end{tabular}

From Table 3, it is known that most of the students choose the digital Qur'an because the Qur'an can be read anytime and anywhere. In other words, the Qur'an reading session is not limited to specific space and time, and does not need special schedule or place. These findings are in line with the reasons given by respondents regarding the digital Qur'an function which can be seen in Table 4.

Table 4

\begin{tabular}{|l|l|}
\hline AlQuran digital function & Total respondent \\
\hline $\begin{array}{l}\text { More diligent (istiqomah) in } \\
\text { reading the Qur'an }\end{array}$ & 78 respondents \\
\hline To support in doing homework & 21 respondents \\
\hline $\begin{array}{l}\text { To support in remembering the } \\
\text { Qur'an }\end{array}$ & 30 respondents \\
\hline Just for fun & 8 respondents \\
\hline
\end{tabular}

Interesting results were gathered and presented in the following Table 5.

Table 5. The Frequency And Normative In Reading The Qur'an

\begin{tabular}{|l|l|}
\hline $\begin{array}{l}\text { Taking Wudhu before } \\
\text { reading digital Qur'an }\end{array}$ & Total respondent \\
\hline Always & 20 respondents \\
\hline Seldom & 17 respondents \\
\hline Sometimes & 74 respondents \\
\hline Never & 26 respondents \\
\hline $\begin{array}{l}\text { Are you reciting Al-Quran } \\
\text { everyday? }\end{array}$ & Total respondent \\
\hline Always & 32 respondents \\
\hline Seldom & 42 respondents \\
\hline Sometimes & 63 respondents \\
\hline
\end{tabular}




\begin{tabular}{|l|l|}
\hline Never & 0 respondent \\
\hline
\end{tabular}

From Table 5 above, it appears that the majority of students at Islamic universities are still spend some of their time to read Qur'an everyday. However, some norms in reciting the Qur'an such as whether they perform wudhu before reading the digital Qur'an, only 20 students out of 137 students admitted that they are taking wudhu before reading the digital Qur'an. The data also explained that even 26 students are not even taking wudhu before reading the digital Qur'an. This research further tried to compare the students behavior in reading the printed and digital version of Qur'an.

Table 6. The Comparison of Students Behaviour In Reciting The Digital and Printed Version of Qur'an

\begin{tabular}{|l|l|l|}
\hline Frequency & Digital Qur'an & Printed Qur'an \\
\hline $\begin{array}{l}\text { Reading for 1-2 } \\
\text { times / day }\end{array}$ & 109 & 99 \\
\hline $\begin{array}{l}\text { Reading for 3-4 } \\
\text { times / day }\end{array}$ & 17 & 23 \\
\hline $\begin{array}{l}\text { Reading for 5-6 } \\
\text { times / day }\end{array}$ & 7 & 10 \\
\hline $\begin{array}{l}\text { Reading }>7 \text { times / } \\
\text { day }\end{array}$ & 4 & 5 \\
\hline Total Verses & Digital Qur'an & Printed Qur'an \\
\hline$>20$ verses / day & 25 & 56 \\
\hline $16-20$ verses / day & 17 & 26 \\
\hline $10-15$ verses / day & 36 & 24 \\
\hline$<10$ verses / day & 59 & 31 \\
\hline
\end{tabular}

Table 6 above illustrated that the printed Qur'an is still more superior in terms of pushing students to read Qur'an diligently. Based on the number of verses read, more respondents are noted to read printed Qur'an more than 20 verses a day (a total of 56 respondents) rather than reading digital Qur'an. The data signed a dilemma of reading the digital Qur'an. In one hand, it has been developed to support people to read Qur'an more diligently, but on the other hand it turns out that the digital Qur'an function is not as good as the printed Qur'an in stimulating students to read Qur'an diligently. Lastly, this research is tried to compare the effect of reciting the printed and digital Qur'an on students.

Table 7. Comparing The Effect of Reciting Printed and Digital Qur'an

\begin{tabular}{|l|l|l|}
\hline $\begin{array}{l}\text { Direct effect of reciting } \\
\text { Qur'an }\end{array}$ & $\begin{array}{l}\text { Digital } \\
\text { Qur'an }\end{array}$ & $\begin{array}{l}\text { Printed } \\
\text { Qur'an }\end{array}$ \\
\hline Become a better human & 15 & 19 \\
\hline Calming & 84 & 113 \\
\hline No effect & 38 & 5 \\
\hline Restless & 0 & 0 \\
\hline
\end{tabular}

Table 7 explained that the effect of printed Qur'an is higher than the digital Qur'an. Some students (38 respondents) even mentioned that the got no effect when they read digital. 


\section{Discussion}

The results of this study provide an overview of the use of digital Qur'an among Islamic university students. In the midst of the digital age and the increase of various digital application which support human life, the existence of digital Qur'an as a replacement of printed Qur'an is still need to be considered from several aspects. This study indicated that there is still a high demand of the printed version of Qur'an among the young Muslims. It seems that they have not fully switched to using digital Qur'an only.

In terms of function, digital Qur'an is indeed able to attract the interest of young people, because through one application, individuals can have various features, such as audio function, checking the tajweed (the best way in reciting the Qur'an). The easy access to Qur'an in which it can be read anytime and anywhere with no specific schedule and place has undoubtly greatly attract young Muslims generation.

Based on some facts found in this research, it can be summed up that several students are still fond of using the printed Qur'an rather than digital Qur'an. This interesting phenomenon should call of further research about some factors affecting the students' choices. Possible factor that might affects the choice is that the students accept Qur'an as a sacred book that might not be replaced by the digital version. However, the fact that the students do not taking wudhu before reciting digital Qur'an contradicts the former idea. By considering this gap, how far the sanctity and sacredness of the digital Qur'an need to be revisited in this globalization era.

Another issue that comes up in this study is the convenience factor. Several students mentioned that the light of the mobile phone has made their eyes irritating and tired. This reason actually signed the level of the technology integration. There should be follow up research about the level of the technological acceptance among young Muslims in Indonesia.

\section{Conclusion}

From this research, it can be concluded that the technological integration in Islamic sector should be investigated. Although the application of technology has helped a lot in our every day life, the technology integration in the religious area are still contradictive. It faces positive and negative reaction from the users. As the technology noted to give several benefits, some modifications in the technology are still needed in order to be able to increase the level of religiosity of young Indonesian Muslim.

\section{References}

[1] J. Naisbitt and N. Naisbitt, "High Tech High Touch Pencarian Makna di Tengah Perkembangan Pesat Teknologi (terjemahan Dian R. Basuki)," Bandung: Misan, 2002.

[2] M. K. Khan and Y. M. Alginahi, "The holy Quran digitization: Challenges and concerns," Life Science Journal, vol. 10, pp. 156-164, 2013.

[3] F. Razaly, N. Ajizan, S. Saad, M. Yaacob, M. Zain, M. Hussein, et al., "User friendly system for the visually impaired in learning Al-Quran," WSEAS Transactions on Systems, vol. 9, pp. 659$668,2010$. 
[4] Y. O. M. Elhadj, "E-Halagat: An e-learning system for teaching the holy Quran," Turkish Online Journal of Educational Technology-TOJET, vol. 9, pp. 54-61, 2010.

[5] M. Al-Yahya, H. Al-Khalifa, A. Bahanshal, I. Al-Odah, and N. Al-Helwah, "An ontological model for representing semantic lexicons: an application on time nouns in the holy Quran," Arabian Journal for Science and Engineering, vol. 35, p. 21, 2010.

[6] H. Saul, "Isis propaganda: Study finds up to 90,000 Twitter accounts supporting extremist group," Independent, March, vol. 6, 2015.

[7] J. C. Ogbogu, "Nigeria's Approach to Terrorist Rehabilitation," Counter Terrorist Trends and Analyses, vol. 8, pp. 16-21, 2016.

[8] F. Faradila, B. Pramono, and N. F. Muchlis, "APLIKASI AL-QUR'AN BERBASIS ANDROID MENGGUNAKAN METODE SEQUENTIAL SEARCH," semanTIK, vol. 2, 2016.

[9] H. Supriyono, A. Nur Saputra, E. Sudarmilah, and R. Darsono, "Rancang bangun aplikasi pembelajaran hadis untuk perangkat mobile berbasis Android," Jurnal Informatika (JIFO), vol. 8, pp. 907-920, 2014.

[10] E. Satria and R. Cahyana, "Pengembangan Aplikasi Zakat Berbasis Android Menggunakan Metode Prototype," Jurnal Algoritma, vol. 11, 2015.

[11] A. T. Septiawan, "Pengenalan Dan Pembelajaran Cara Membaca Alquran (Ilmu Tajwid) Berbasis Mobile Android," Universitas Muhammadiyah Surakarta, 2012.

[12] M. Y. Herdiansyah and I. Afrianto, "Pembangunan Aplikasi Bantu Dalam Menghafal AlQur'an Berbasis Mobile," Jurnal ilmiah komputer dan informatika (KOMPUTA), 2013.

[13] S. Elvrilla, "Augmented Reality Panduan Belajar Sholat Berdasarkan Buku Teks Belajar Sholat Menggunakan Android," 2011.

[14] M. Z. Atiroh and E. Satria, "Rancang Bangun Aplikasi Fiqih Ibadah Shalat Berbasis Android," Jurnal Algoritma, vol. 11, 2015.

[15] H. Nufus, N. Solekhah, M. Sarosa, and M. N. Zakaria, "Rancang Bangun Aplikasi Al Quran Digital Untuk Penyandang Disabilitas Tangan Berbasis Command Voice Pada Perangkat Android," Proceeding SENDI U, 2015.

[16] M. F. H. Ansori and B. M. M. Kom, "Perancangan Media Pembelajaran Iqra Bagi Anak Usia Dini Berbasis Android," Universitas Muhammadiyah Surakarta, 2016.

[17] E. Qualman, Socialnomics: How social media transforms the way we live and do business: John Wiley \& Sons, 2010.

[18] A. Aulia, D. Khairani, and N. Hakiem, "Development of a retrieval system for Al Hadith in Bahasa (case study: Hadith Bukhari)," in 2017 5th International Conference on Cyber and IT Service Management, CITSM 2017, 2017. 